\title{
CORRECTION
}

\section{Correction to: Encrypted gray image transmission over OFDM channel for TV cloud computing}

\author{
Salwa M. Serag Eldin ${ }^{1,2} \cdot$ Mohammed A. Alsharqawy $^{3}$
}

Published online: 18 August 2020

(c) Springer Science+Business Media, LLC, part of Springer Nature 2020

Correction to: Int J Speech Technol (2017) 20:431-442 https://doi.org/10.1007/s10772-017-9415-3

Mohammed A. Alsharqawy is co-author of above mentioned article, but was not listed in the author group of the original article.

Publisher's Note Springer Nature remains neutral with regard to jurisdictional claims in published maps and institutional affiliations.

The original article can be found online at https://doi.org/10.1007/ s10772-017-9415-3.

Salwa M. Serag Eldin

sserag@gmail.com; s.alsaeed@tu.edu.sa

Mohammed A. Alsharqawy

mnm_1946@hotmail.com

1 Electronics and Electrical Communications Engineering Department, College of Engineering, Tanta University, Tanta, Egypt

2 Computer Engineering Department, College of Computers and Information Technology, Taif University, Taif,

Saudi Arabia

3 Egytian Radio and Television Union, Cairo 1186, Egypt 